\title{
Electric Vehicle Battery Reuse: Preparing for a Second Life
}

\author{
Lluc Canals Casals (iD), Beatriz Amante García (iD, Lázaro V. Cremades (iD) \\ Universitat Politècnica de Catalunya (UPC) (Spain) \\ lluc.canals@upc.edu, beatriz.amante@upc.edu,Llazaro.cremades@upc.edu
}

Received: June 2016

Accepted: January 2017

\section{Abstract:}

Purpose: On pursue of economic revenue, the second life of electric vehicle batteries is closer to reality. Common electric vehicles reach the end of life when their batteries loss between a 20 or $30 \%$ of its capacity. However, battery technology is evolving fast and the next generation of electric vehicles will have between 300 and $400 \mathrm{~km}$ range. This study analyzes different End of Life scenarios according to battery capacity and their possible second life's opportunities. Additionally, an analysis of the electric vehicle market, EV manufacturers and environmental impact defines a possible location for battery repurposing or remanufacturing plants.

Design/methodology/approach: Using the center of mass equation taking 3 parameters: electric vehicle market, manufacturers and environmental impact this study suggests a location to settle a battery repurposing plant from a logistic and environmental perspective.

This paper presents several possible applications and remanufacture processes of EV batteries according to the state of health after their collection, analyzing both the direct reuse of the battery and the module dismantling strategy.

Findings: The study presents that Germany seems a good location to build a battery repurposing plant because of its closeness to EV manufacturers and the potential European EV markets, observing a strong relation between the EV market share and the income per capita.

$9 \%$ of the batteries may be send back to an EV as reposition battery, $70 \%$ will be prepared for stationary or high capacity installations such as grid services, residential use, Hybrid trucks or 
electric boats. Finally, the remaining $20 \%$ is to be dismantled into modules or cells for smaller applications, such as bicycles or assisting robots.

Originality/value: Most of studies related to the EV battery reuse take for granted that they will all have an $80 \%$ of its capacity. This study analyzes and proposes a distribution of battery reception and presents different $2^{\text {nd }}$ life alternatives according to their state of health.

Keywords: electric vehicle, battery, reuse, second life, remanufacture

\section{Introduction}

The environmental impact of the ongoing world's industrialization is increasing year after year (Pachauri, Allen, Barros, Broome, Cramer \& Christ, 2014). The self-called developed countries have been and are major contributors to this impact (Botzen, Gowdy \& Bergh, 2008; Heil, 1997). Lastly, most of them accepted their responsibility during the Climate Conference that took place in Paris in 2015 and, for the first time ever, 195 countries adopted a legally binding global climate deal (UNFCCC, 2015). The most significant goal is a long-term global temperature increase below $2^{\circ} \mathrm{C}$, achieving the greenhouse gas emission's peak as soon as possible and a fast reduction afterwards. Although promising, this adoption may be insufficient for the continuity of many regions and ecosystems while some scientific studies classified it as dangerous limit (Fernández-Reyes, 2014; Hansen, Kharecha, Sato, Masson-Delmotte, Ackerman, Beerling et al., 2013; Schewe, Levermann \& Meinshausen, 2010). Additionally, the capacity of countries and society to apply it generates some doubts.

However, decarbonization of electricity generation is compulsory to achieve the planned goals. In fact, decarbonization has already started in Europe, as the last IEA Energy Policy report highlighted that, for example, U.K. has done the largest reform since privatization to increase renewable share, Denmark plans major investments to generate 50\% of electricity from wind by 2020 and Netherlands increased the subsidies in renewable energy generation (IEA, 2013).

Moreover, if renewable energy sources should increase their integration rate, they may need some energy storage systems (ESS) to provide them more stability and reliability (Lymperopoulos, 2014). Batteries are one of the energy storage technologies called to provide some of the expected electricity grid services (Rastler, 2010). In particular, lithium ion batteries, which are the ones that have wider working opportunities (Dunn, Kamath \& Tarascon, 2011), are still too expensive for an extensive installation abroad. 
On the other hand, most of the commercialized electric vehicles (EV, including Plug-in Hybrid Electric Vehicles (PHEV) and full electric vehicles (BEV)) use Lithium ion batteries as ESS (Gil-Agusti, Zubizarreta, Fuster \& Quijano, 2014). These batteries achieve their End-of-Live (EoL) when their capacity is reduced by a $20 \%$ or, in other words, when they reach an $80 \%$ of their State Of Health (SOH) (Guenther, Schott, Hennings, Waldowski \& Danzer, 2013). Thus, EV batteries should be recycled while they still have an $80 \%$ of their available capacity.

In consequence, the idea of EV battery re-use appeared to offer low price batteries for stationary applications while, at the same time, this battery selling may provide some revenue back to car manufacturers. Moreover, these additional incomes may revert in lower EV selling prices, making EVs more competitive (Jiao \& Evans, 2016). Thus, there is a need to manage these $2^{\text {nd }}$ life batteries.

This study analyzes some of the $2^{\text {nd }}$ life opportunities, exploring more precisely the EoL of batteries and searching a possible location for a battery remanufacture plant under a productive and environmental perspective.

However, this paper treats with battery standard systems from common EV, discarding premium EV brands, as they are not affordable for most of people and their designs do not specifically follow the paths towards sustainability.

\section{Methodology}

The structure of this study regards 4 aspects to take into account when dealing with second life batteries: A first sub-section analyzes some EoL considerations before deciding what to do with aged EV batteries. Secondly, the study presents the available remanufacturing processes. In the third sub-section, the study analyzes some second life market opportunities for EV batteries. Finally, the study calculates an appropriate location of a remanufacturing plant in Europe considering the number of EV sold per vehicle, the distances around Europe, main EV manufacture locations and the countries commitment with electricity grid decarbonization. 


\subsection{End of Life Considerations}

The EoL of EV batteries, as stated in the introduction, is commonly defined when their $\mathrm{SOH}$ reaches the $80 \%$. Car manufacturers fixed this $\mathrm{SOH}$ limit for marketing reasons in front of real impediments. Effectively, power and efficiency losses appear when batteries age, but they do not really interfere with driving safeness. Instead, the capacity loss of the battery, being directly related to the mileage an EV may run with a fully charged battery, is easier to detect than power loss (Andrew, 2009). Thus, capacity fade became the main reason for this $\mathrm{SOH}$ limitation. Common EVs have a driving range around $140 \mathrm{~km}$ before recharging, which means that, with an $80 \%$ of its capacity, the EV driving range reduces to 112 $\mathrm{km}$.

There are plenty of methodologies to estimate SOH, such as the simple coulomb counting (Burns, 2011), voltage recovery (Canals Casals, Schiffer-González, Amante García \& Llorca, 2015) or more demanding calculation algorithms using support vector machines or particle filters among others (Barré, Deguilhem, Grolleau, Gérard, Suard \& Riu, 2013; Williard, Tsui \& Pecht, 2011; Zhang \& Lee, 2011). Thus, it is possible to determine the moment when batteries reach this EoL during the vehicle use phase or during their first life.

However, even having the tools to determine $\mathrm{SOH}$, car manufacturers do not expect clients to return the vehicle at this precise moment for several reasons: First, most of the EV models do not show this SOH value. Second, season weather, temperature changes and the use of auxiliary loads (as heater, cooler, etc.) affect the battery performance, making it difficult for the owner to precisely appreciate this moment (Canals Casals, Amante García \& Castellà-Dagà, 2016). Finally, the third reason interfering on EV returns is that it is still hard to predict how EV owners will use their cars, as an $80 \% \mathrm{SOH}$ criterion may still fulfill the necessities of the majority of EV owners (Saxena, Le Floch, Macdonald \& Moura, 2015) and they may extend car's lifespan well beyond this limit.

These three indeterminations make it difficult to estimate the $\mathrm{SOH}$ distribution of returned EVs. Moreover, the average estimated lifespan of common vehicles is visibly different depending on the country, which aggravates the difficulties to determine the appropriate $\mathrm{SOH}$ distribution at the EoL. In fact, a study of vehicle disposal shows that Even within Europe, car average lifespan goes from less than 10 years in Belgium to almost 20 in Spain and Portugal (Oguchi \& Fuse, 2015). This same study indicates that a Weibull distribution is often used to model failure rate of technical goods, although it acknowledges that other statistic functions are used too. Heiskanen et al. supported the idea that a Weibull function is best adapted to European reality (Heiskanen, Kaila, Vanhanen, Pynnönen \& Silvennoinen, 2013). Similarly, Müller et al. compared Normal, Weibull and Lognormal functions in the US and stated that normal distribution was the one giving best results (Müller, Cao, Kongar, Altonji, Weiner \& Graedel, 2007). However, EV battery replacement do not respond to failure but to its degradation according to its 
use. These concepts are close but they are not the same thing, as EVs may still respond to their owners' necessities even though they reached the accepted 80\% SOH EoL criteria (Saxena et al., 2015). In all cases, the goodness of fit was not that different between a Normal and a Weibull distribution being their average lifespan much longer than most EVs' expectations.

Having no data available of EVs at their EoL, studies estimated EV batteries' lifespan taking into consideration several aspects, such as climatologic conditions or driving habits among others. An study that analyzes the expected SOH of several PHEVs after the 8 years, presents that the SoH distribution at the EoL of PHEVs battery with higher driving range fit to a normal distribution while those PHEVs with lower driving range are closer to Weibull distribution (Smith, Earleywine, Wood, Neubauer \& Pesaran, 2012). Taking into account that EVs have even higher driving ranges than most of PHEVs it seems a good assumption to use a normal distribution to estimate battery $\mathrm{SOH}$ at the EoL of the vehicle. Moreover, a normal distribution similar to the one presented below was used in the study by Keeli and Sharma to estimate battery SOH at the beginning of second life (Keeli \& Sharma, 2012).

Therefore, and knowing that the $\mathrm{SOH}$ at $80 \%$ limit is still under, we decided to take a normal distribution centered at $80 \% \mathrm{SOH}$ and with the $95^{\text {th }}$ and $5^{\text {th }}$ percentile at 90 and $70 \% \mathrm{SOH}$, represented in Figure 1. This distribution considers only functionally correct batteries. Damaged batteries or batteries from cars that suffered important accidents are not considered for this study. Nonetheless, it should be acknowledged that the number of batteries recovered will be significantly lower than the number of EV and PHEV sold because of that.

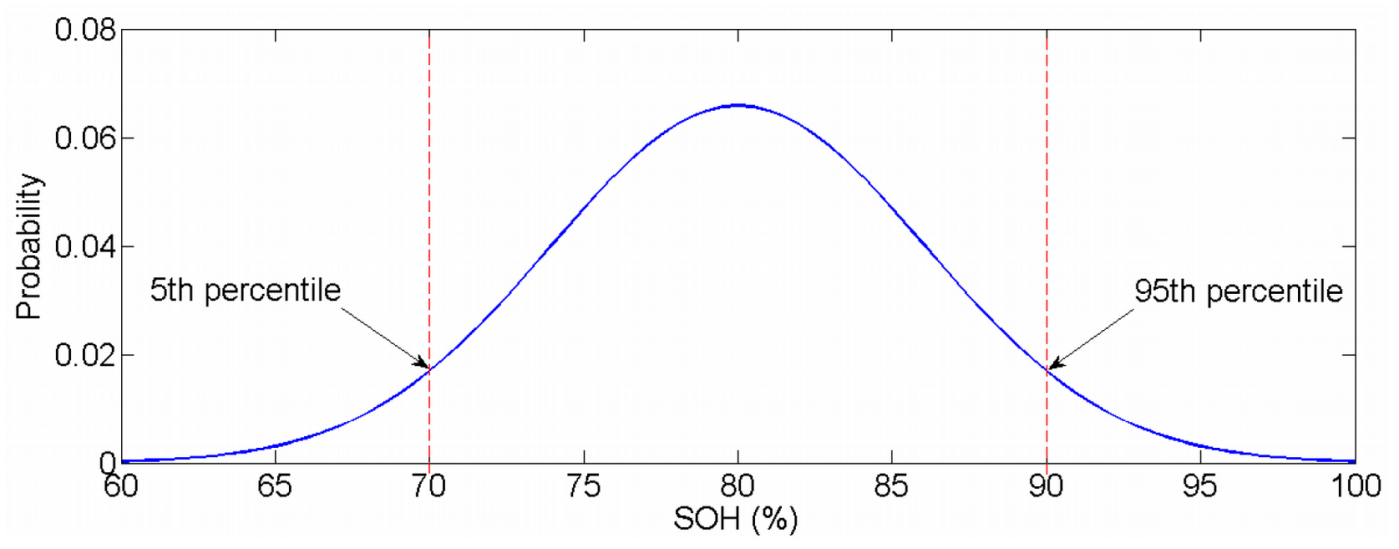

Figure 1. Assumed normal distribution for $\mathrm{SOH}$ EV return 
All these appreciations are further exaggerated in the case of PHEV vehicles, as they can also run using fuel oil derivate, allowing owners to enlarge their lifetime even more.

Finally, the next generation of EVs will have better performances. With higher energy and power densities, batteries will offer longer vehicle ranges around $300 \mathrm{~km}$ or more. Thus, considering the $3^{\text {rd }}$ reason interfering on EV return related to the EV owner's use described above in this same section, the EoL of these forthcoming EV generations will need to be revised, as it will certainly decrease to lower values $(70-60 \% \mathrm{SOH})$.

\subsection{Remanufacturing Processes}

There are three different remanufacture or repurposing processes to deal with $2^{\text {nd }}$ life batteries from EV: Direct reuse, module dismantle and cell dismantle.

The fastest and cheapest one is the direct reuse. That is, take the EV battery as it comes, check its $\mathrm{SOH}$ and functional characteristics and add the minimum adaptations for its second life. This strategy is the one followed by some car manufacturers on their EV batteries $2^{\text {nd }}$ life demonstrative projects, such as Sunbatt (Cruz-Gibert, Cruz-Zambrano, Canals Casals, Castellà-Dagà \& Díaz-Pinos, 2015) or Batteries second life (Gohla-Neudecker, Bowler \& Mohr, 2015).

Another option is to dismantle the battery into modules to pack them up again in another configuration, grouping the modules by similar characteristics. This process was first proposed by Cready, Lippert, Pihl, Weinstock, Symons and Jungst (2003). It has more energy and work demand than the direct battery reuse, but it offers better adapted second life batteries (Ahmadi, Fowler, Young, Fraser, Gaffney \& Walker, 2014).

The last option is to completely dismantle the battery to a cell level. Then, as it happened with the module strategy, cells are grouped by remaining capacity or $\mathrm{SOH}$. An example of this methodology was used in a 172 cells battery design for an Off-grid photovoltaic system (Tong, Same, Kootstra \& Park, 2013) or by Relectrify company, which uses laptop aged batteries to prepare new battery sets. However, this latter option is scarcely analyzed for several reasons: It demands harder work to dismantle the battery and to pack it up again, ending up in a more expensive process. EV cell dismantling may also be complicated and delicate, as cells can be somehow glued during the module fabrication and the dismantle process may damage cells. 


\subsection{Second Life Opportunities}

There are plenty of battery reuse options depending on the remanufacture process and its $\mathrm{SOH}$ at collection. Figure 2 presents a summarizing schema of the flow diagram that batteries should follow at the end of their life on EVs.

The dashed square in Figure 2 identifies the $1^{\text {st }}$ life stages of the battery. After that, there is the battery collection and a first selection, where damaged batteries are considered useless and should go directly to recycle even before studying its $\mathrm{SOH}$ for safety concerns.

Functional batteries arrive to the remanufacture plant where they are submitted to SOH tests. Marked by a circled number 1 in Figure 2, batteries resulting in $\mathrm{SOH}$ above $88 \% \mathrm{SOH}$ will certainly be send back to a $1^{\text {st }}$ life as spare parts to replace damaged or older batteries. This is the easiest and fastest way to participate into the circular economy. Moreover, this battery may enter to the following loops of the circular economy afterwards.

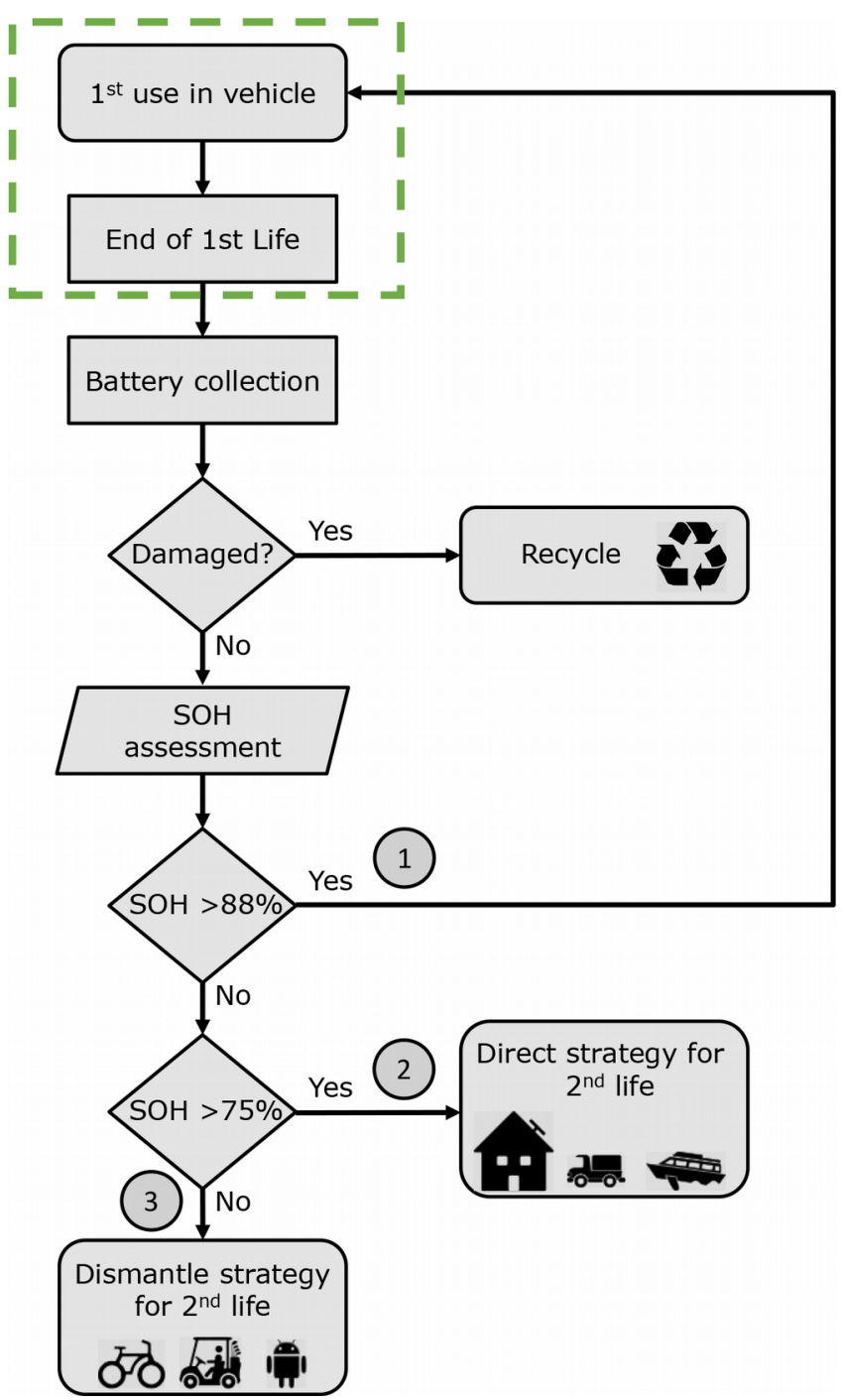

Figure 2. Decision making flow diagram for batteries at the end of its $1^{\text {st }}$ life on EVs 
The second option (number 2 in Figure 2) is that batteries having between an 88 and 75\% SOH can be offered for stationary applications. There are many applications where batteries may provide services: renewable firming, self-consumption, peak shaving or uninterrupted power supply systems are some applications on commercial buildings and industry, however, there are other grid-oriented energy services such as area or frequency regulation and transmission deferral (Gyuk, Jonson, Vetrano, Lynn, Parks, Handa et al., 2013; Neubauer, Simpson, Neubauer \& Simpson, 2015; Muenzel \& Mareels, 2015; Akhil, Huff, Currier, Kaun, Rastler, Chen et al., 2013). These latter two options are the ones having more economic interest according to the EPRI report (Rastler, 2010). Most of these options seem fine for $2^{\text {nd }}$ life applications, however, they should be carefully studied and analyzed in order to avoid the so called "aging knee", which is a sudden change in the in the aging evolution due to a variation of the main aging mechanism (Martinez-Laserna, Sarasketa-Zabala, Stroe, Swierczynski, Wamecke, Timmermans et al., 2016).

Within this $88-75 \% \mathrm{SOH}$ range, batteries may also be used on other transportation services with lower load requirements. An option that car manufacturers are dealing with is the reuse of these batteries as a power support to new hybrid trucks designed for urban areas. These batteries may be used in the start and stop driving cycles of cities, where the acceleration after traffic lights with $1^{\text {st }}$ and $2^{\text {nd }}$ gears are common, noisy and very pollutant. In these cases, batteries provide the necessary power to accelerate the truck for short time lapses and recharge when the internal combustion engine starts and runs at more stable rpm. This would make hybrid trucks considerably cheaper and quite more attractive.

Still on transportation, these batteries could be installed on boats and ferries to be used during the entrance and exit maneuvers in ports, eliminating noise and, most important, pollution.

Finally, marked by a circled 3 in Figure 2, batteries with lower $\mathrm{SOH}$ are the ones called to be dismantled into modules or cells. EV cells are further more developed than common batteries for smaller devices, such as laptops or electric bicycles, which are less expensive and easily replaceable. Thus, aged EV cells could be compared to brand new cells for these devices. Additionally, mobile systems for human assistance, like cleaning or medical robots that move around an enclosed space at low velocities, can use these remanufactured modules from dismantled EV batteries instead of the actual lead acid batteries. Moreover, another final use of remanufactured modules can be low demanding electric vehicles, such as golf vehicles or transpallets in warehouses or logistic nodes among other options. 


\subsection{Remanufacture Plant Location}

The calculation of an appropriate location to place a battery remanufacture plant is carried out following the center of mass equation. In physics, the center of mass of distributed particles in space is the point where the weighted relative position of the distributed mass sums zero (Equation 1).

$$
X=1 / m_{T} \cdot \sum m_{i} \cdot x_{i}
$$

Where $X$ are the coordinates of the barycenter, $m_{T}$ refers to the total mass of particles in the system and $m_{i}$ and $X_{i}$ are the mass and coordinates of particle $i$.

Equation 1 was adapted to our case incorporating three parameters in order to determine the location to build the battery remanufacture plant: The number of sold EVs during the last years, the actual location of EV manufacture plants and the expected investments per country related to reduce the environmental impact of the electricity generation and distribution grid.

First, the study relies on the number of EVs and PHEVs sold in the European countries that sold more than 7.000 EVs during the last years (Table 1) to calculate the distance to the manufacture plant by adapting the center of mass equation.

\begin{tabular}{|c|c|c|c|c|c|c|c|}
\hline Country & 2010 & 2011 & 2012 & 2013 & 2014 & 2015 & Total \\
\hline Netherlands & 155 & 953 & 5.492 & 22801 & 15.835 & 43.350 & 88.586 \\
\hline France & 980 & 4.349 & 9.981 & 14725 & 16.805 & 27.081 & 73.921 \\
\hline Norway & 356 & 2.043 & 4.350 & 8564 & 20.328 & 34.336 & 69.977 \\
\hline Germany & 545 & 2.466 & 4.850 & 7968 & 13.804 & 24.171 & 53.804 \\
\hline U.K. & 250 & 1.165 & 2.532 & 3773 & 15.292 & 28.188 & 51.200 \\
\hline Sweden & 9 & 189 & 1.217 & 1719 & 4.964 & 9.039 & 17.137 \\
\hline Switzerland & 205 & 505 & 1.126 & 1869 & 2.789 & 6.421 & 12.915 \\
\hline Denmark & 64 & 477 & 684 & 654 & 1.704 & 4.762 & 8.343 \\
\hline Belgium & 67 & 280 & 850 & 724 & 1.798 & 3.899 & 7.618 \\
\hline Austria & 135 & 685 & 990 & 1032 & 1.921 & 2.801 & 7.564 \\
\hline Italy & 323 & 383 & 1.000 & 1329 & 1.771 & 2.462 & 7.268 \\
\hline Spain & 130 & 480 & 711 & 951 & 1.804 & 3.015 & 7.091 \\
\hline Total & 3.242 & 14.185 & 33.894 & 66346 & 99.131 & 189.525 & 405.426 \\
\hline
\end{tabular}

Table 1. European EV selling from 2010 to 2015. Source: European Automobile Manufacturers Association (ECEA)

Incidentally, by taking into consideration the demography per country, in order to distribute these EV selling according to the population on each country, this study considers the three most populated cities 
per country. In fact, cars finish their life in authorized treatment centers (ATC) for dismantling and recycling. In some cases, car dealers are the ones receiving the old cars and they manage the shipment to the ATC. Thus, ATCs will be the ones collecting the batteries and sending them to the remanufacture plant. It occurs that most ATC and car dealers are found near populated cities, Table 2 presents the three most populated cities per country and its respective population share considering only these cities.

\begin{tabular}{|l|l|l|l|l|l|c|}
\hline Country & \multicolumn{1}{|c|}{ City 1 } & Share & \multicolumn{1}{c|}{ City 2} & Share & \multicolumn{1}{c|}{ City 3} & \multicolumn{1}{c|}{ Share } \\
\hline Netherlands & Amsterdam & $42 \%$ & Rotterdam & $32 \%$ & The Hague & $26 \%$ \\
\hline France & Paris & $62 \%$ & Marseille & $24 \%$ & Lyon & $14 \%$ \\
\hline Norway & Oslo & $59 \%$ & Bergen & $25 \%$ & Trondheim & $17 \%$ \\
\hline Germany & Berlin & $52 \%$ & Hamburg & $26 \%$ & Munich & $22 \%$ \\
\hline U.K. & London & $83 \%$ & Birmingham & $11 \%$ & Glasgow & $6 \%$ \\
\hline Sweden & Stockholm & $51 \%$ & Göteborg & $31 \%$ & Malmö & $18 \%$ \\
\hline Switzerland & Zurich & $54 \%$ & Geneve & $25 \%$ & Basel & $21 \%$ \\
\hline Denmark & Copenhagen & $74 \%$ & Aarhus & $15 \%$ & Odense & $10 \%$ \\
\hline Belgium & Antwerpen & $53 \%$ & Gent & $26 \%$ & Charleroi & $21 \%$ \\
\hline Austria & Wein & $79 \%$ & Graz & $12 \%$ & Linz & $9 \%$ \\
\hline Italy & Roma & $55 \%$ & Milano & $26 \%$ & Napoli & $19 \%$ \\
\hline Spain & Madrid & $57 \%$ & Barcelona & $29 \%$ & Valencia & $14 \%$ \\
\hline
\end{tabular}

Table 2. Most populated cities per country and their population share

The annual income per capita or citizen's economic wealth is indirectly taken into account when discussing the location of the remanufacture plant. In fact, there is a relation between the annual income per capita and the number of EV sold, as it is further explained in the discussion section.

Assuming that some batteries may go back to EV manufacture plants, this study considers the allocation of manufacture plants from EVs having more than a $6 \%$ of the market share. Table 3 summarizes the information of model, manufacturer, market share and plant location. Additionally, as the battery capacity of average BEV doubles PHEV's battery capacity, having bigger and more interesting batteries to rework, the weight of BEV's in the center of mass equations increases by doubling the number of models produced. This change implies, for example, that models ranked 2 and 4 in Table 3 take the first and second position. However, this parameter considers only the vehicles build in Europe, thus, model number 1 and 4 have no impact in the calculations. 


\begin{tabular}{|c|c|c|c|c|c|c|}
\hline Rank & Manufacturer & Model & 2015 Selling & $\%$ BEV + PHEV & \% BEV & Fabrication plant \\
\hline 1 & Mitsubishi & Outlander & 31.340 & $16 \%$ & - & Nagoya (Japan) \\
\hline 2 & Renault & Zoe & 18.670 & $10 \%$ & $19 \%$ & Flins (France) \\
\hline 3 & Volkswagen & Golf GTE & 17.282 & $9 \%$ & - & Wolfsburg (Germany) \\
\hline 4 & Tesla & Model S & 16.455 & $9 \%$ & $16 \%$ & Freemont (USA) \\
\hline 5 & Nissan & Leaf & 15.515 & $8 \%$ & $15 \%$ & Sunderland (U.K.) \\
\hline 6 & BMW & i3 & 11.820 & $6 \%$ & $12 \%$ & Leipzig (Germany) \\
\hline 7 & AUDI & Audi A3 e-Tron & 11.711 & $6 \%$ & - & Ingolstadt (Germany) \\
\hline 8 & Volkswagen & e-Golf & 11.124 & $6 \%$ & $11 \%$ & Wolfsburg (Germany) \\
\hline & Rest EV+PHEV & & 59.522 & $31 \%$ & & \\
\hline & Rest EV & & 39.014 & & $39 \%$ & \\
\hline
\end{tabular}

Table 3. EV manufacturer's plant information and market share

Finally, the environmental impact is also taken into consideration when calculating an appropriate location of a battery remanufacture plant, being the third parameter incorporated in the equation. This study considers the $\mathrm{CO}_{2}$ emissions to produce electricity, which is further used to charge EVs, by taking the daily electricity MIX per country. Electricity MIX emissions presented in Table 4 are extracted from a study of the EV impact in European countries (Canals Casals, Martinez-Laserna, Amante-García \& Nieto, 2016), which took the original data from EUROSTAT databases.

\begin{tabular}{|c|c|c|c|c|c|c|c|c|c|c|c|c|}
\hline Country & Fr & No & Ge & UK & Ne & Sw & Au & It & Sp & De & Se & Be \\
\hline Mix emissions (gCO e.) & 108 & 23 & 561 & 591 & 541 & 40 & 209 & 552 & 320 & 454 & 41 & 277 \\
\hline
\end{tabular}

Table 4. Emissions of the electricity MIX per country

This electricity MIX is also a good indicator of the investments that each country needs to perform in order to improve the environmental impact coming from electricity generation. Therefore, as batteries are called to support renewable energy sources, it is more provable that countries having high electricity MIX values may use more batteries than other countries that solved this problem. For example, Germany and U.K., which use a lot of coal to generate electricity, are expecting to increase their renewable energy generation rate dramatically. On the other side, Norway, where most of the electricity generation takes place on hydraulic power plants, does not need to invest that much on "cleaning" its electricity grid.

Applied to our case, the center of mass equation transforms to Equation 2, where the weight of the three aforementioned parameters is the same, that is, $1 / 3$ each.

$$
X=1 / 3\left(1 / V_{T} \cdot \Sigma V_{i} \cdot S_{i j} \cdot x_{i j}\right)+1 / 3\left(1 / M_{T} \cdot \Sigma M_{i} \cdot L_{i}\right)+1 / 3\left(1 / E_{T} \cdot \sum E_{i} S_{i j} \cdot x_{i j}\right)
$$


In Equation 2, $X$ represents the resulting location of the remanufacture plant, which is shown in figure 4 by a red dot. $V_{T}$ is the total number of sold EVs, $V_{i}$ the number of EVs sold in country $i$ (see Table 1), $S_{i j}$ is the percentage of population from country $i$ living in city $j$ (see Table 2 ) in and $X_{i j}$ are the coordinates of city $i j$. Similarly, $M_{T}$ is the total amount of produced EVs, $M_{i}$ refers to the number of produced vehicles (see Table 3 ) of model $i$ ( $x 2$ if model $i$ is a BEV), which is produced in the city coordinates $L_{i}$. Finally, $E_{T}$ refers to the sum of the electricity $\mathrm{MIX} \mathrm{CO}_{2}$ emission values and $E_{i}$ to the electricity mix of country $i$ (see Table 4 ).

In consequence, France, Germany and U.K. are the only countries having EV manufacture plants, and a relevant amount of EV selling, although France has a quite low environmental factor. On the other side, although Norway is the third major EV selling country in Europe, it has almost no investment or environmental factor and has no relevant EV manufacture plants. Thus, Norway's impact in the calculation of the barycenter is rather low in comparison to the France, Germany or the U.K.

\section{Discussion}

There are more than 20 different car models in the total 405.426 BEV and PHEV sold in Europe from 2010 to 2015, which means that there are more than 20 different type of batteries. This diversity difficults the repurposing strategy.

Car manufacturers warrant a battery lifespan for 8 to 10 years or until the car reaches 100.000 and $150.000 \mathrm{~km}$. In addition to the difficulties to predict the EoL described in section 2.1, the number of batteries received per year depends on other factors, such as: year of EV manufacture; driving habits and mileage per day of the EV owner; climate conditions of the country (high and low temperatures are not recommended for lithium batteries (Waldmann, Wilka, Kasper, Fleischhammer, \& Wohlfahrt-Mehrens, 2014)) or accidents. Thus, it is hard to predict the amount and type of batteries to come in the forthcoming weeks.

According to the specifications defined in section 2.1, the corresponding normal distribution has a mean value at $80 \% \mathrm{SOH}$ and a standard deviation of 6.06 . This distribution defines the percentage of received batteries that would follow each path. That is: $9.34 \%$ of received batteries will go directly to the EV manufacturer plant as spare part for EVs ( $\mathrm{SOH}>88 \%$ ); $70.19 \%$ of remanufactured batteries will go to stationary applications following a direct reuse process; Finally, $20.47 \%$ of recovered batteries will suffer a module dismantling process to build smaller battery packs. 
In the end, all functionally correct batteries are going to arrive to the remanufacture plan, where the remanufacture process will began according to its $\mathrm{SOH}$ as described in section 2.3 and schematically represented in Figure 3.

According to these results and referred literature, the majority of re-manufactured batteries will go to stationary applications, taking part somehow in the electricity infrastructure or back to transportation's manufacture plants. In consequence, second life business opportunities described in section 2.3 have an influence in the calculations of the proposed location for an EV battery remanufacture plant.

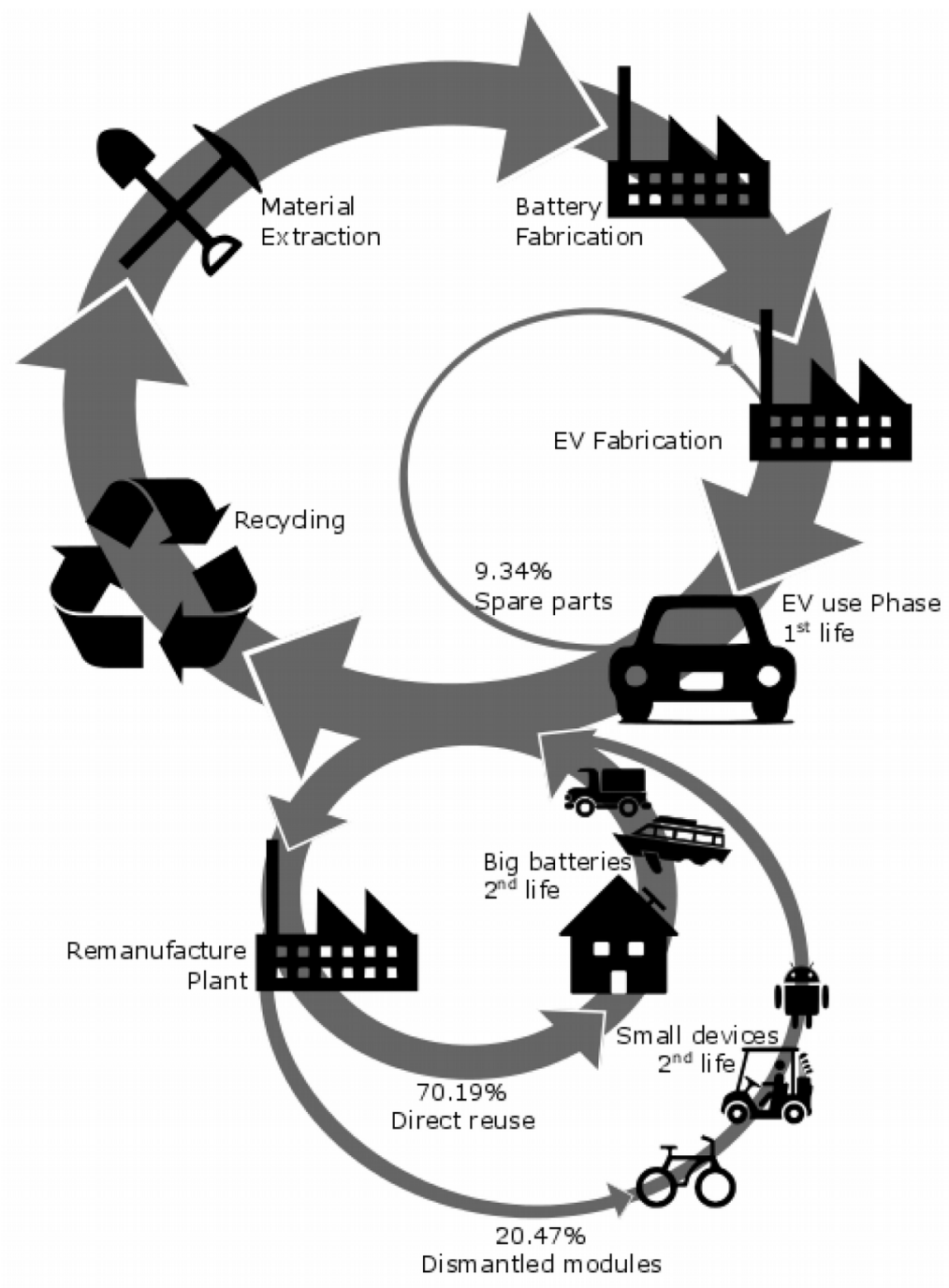

Figure 3. Schema of the circular economy paths

All these batteries should go to the remanufacture plant for testing and preparation for the $2^{\text {nd }}$ life. Figure 4 presents four barycenter results according to the different parameters involved. It is interesting to notice that all barycenters fall inside Germany. The barycenter concerning EV selling and distribution (dark blue 
dot in Figure 4) is the one ending northern, being close to the village of Finnentrop. Close to it, the barycenter considering remanufacture plants falls near the town of Montabaur (yellow dot in Figure 4). It is not surprising that this barycenter ends up in Germany, as three of the five most EV selling European manufacturers produce their EVs there. Finally, the barycenter ending southern is the one regarding the environmental impact or the expected electricity grid investments, which showed to be near the city of Freudenstadt (Orange dot in Figure 4).

The average of these 3 barycenter marks the final proposal for the remanufacture plant and corresponds to " $\mathrm{X}$ " in Equation 2. Thus, the town of Wiesbaden or its surroundings, being Frankfurt the closer major city, seem a good spot to locate the remanufacture plant.

It is not surprising that the center of mass falls into Germany. It is one of the countries with higher EV selling and manufacturing, what is relatively shocking is that it is also one of the countries with higher electricity environmental impact. In fact, as Figure 4 shows, it is the only country where the values of the 3 parameters included in the center of mass equation are high. The other countries having three parameters, namely U.K. and France, have lower car manufacturer impact and France is the $4^{\text {th }}$ country with lower electricity MIX emissions in Europe, thus, less weight to attract the barycenter.

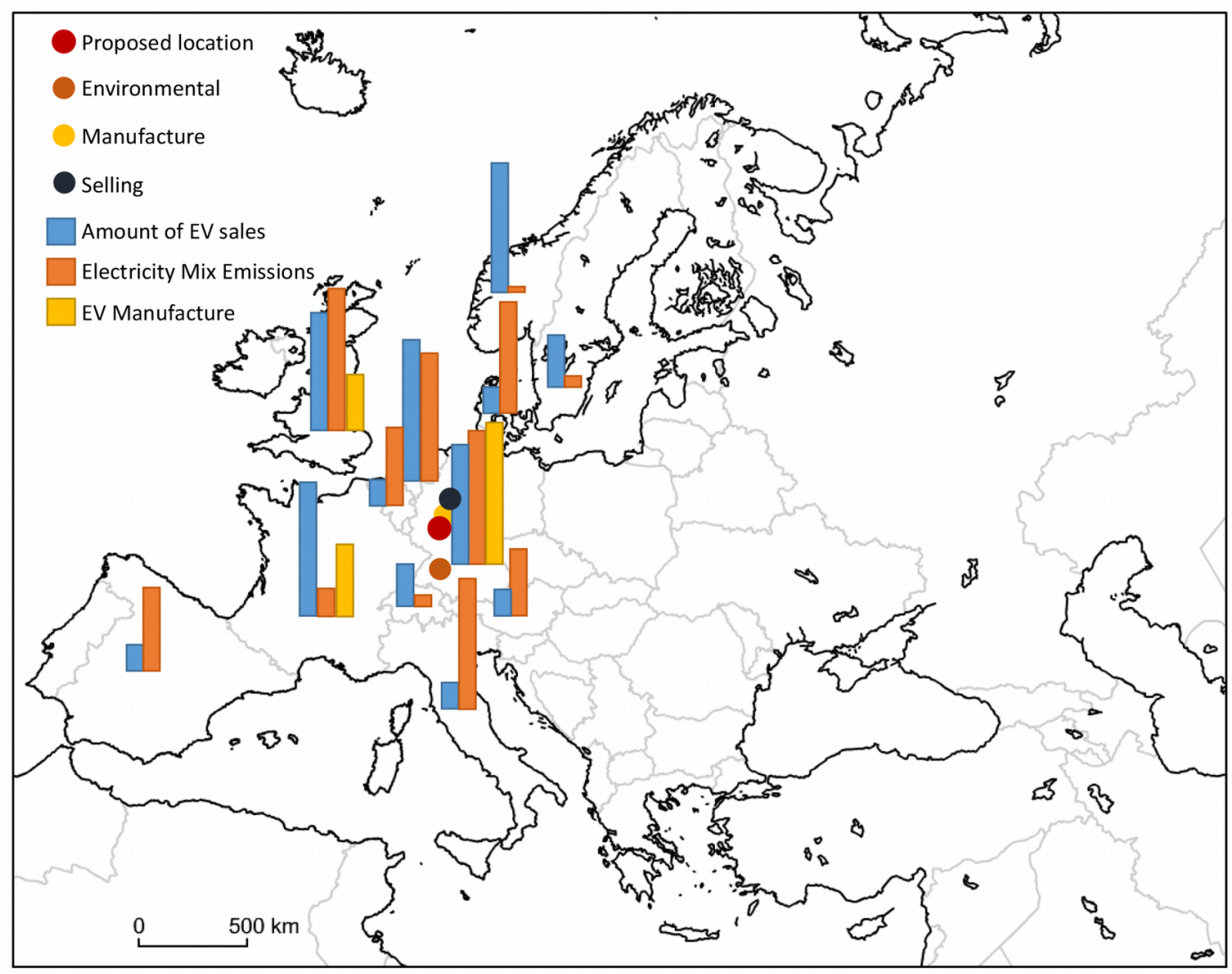

Figure 4. Impact of each parameter in the center of mass calculation per country.

Dots indicate global and individual barycenter from Equation 2 
However, a closer look into economics reveals that EV market share has a strong correlation against income per capita, as it is appreciable in Figure 5. In fact, Figure 5 also reflects the positive impact of fiscal, financial and practical incentives for EV adoption (the outstanding case of Norway is a clear example, with a market share close to the $14 \%$, far beyond all other countries not reaching the $2 \%$ of the market share in the best case) and the implication of local car manufacturers (being France the most relevant case) as Sierzchula et al. pointed out in their study (Sierzchula, Bakker, Maat, \& Van Wee, 2014).

Therefore, as EV prices are not expected to decline in the nearby future and the average income per capita of less wealthy European countries is not foreseen to increase dramatically, the location of the remanufacture plant seems a good selection.

\section{EV market share vs income}

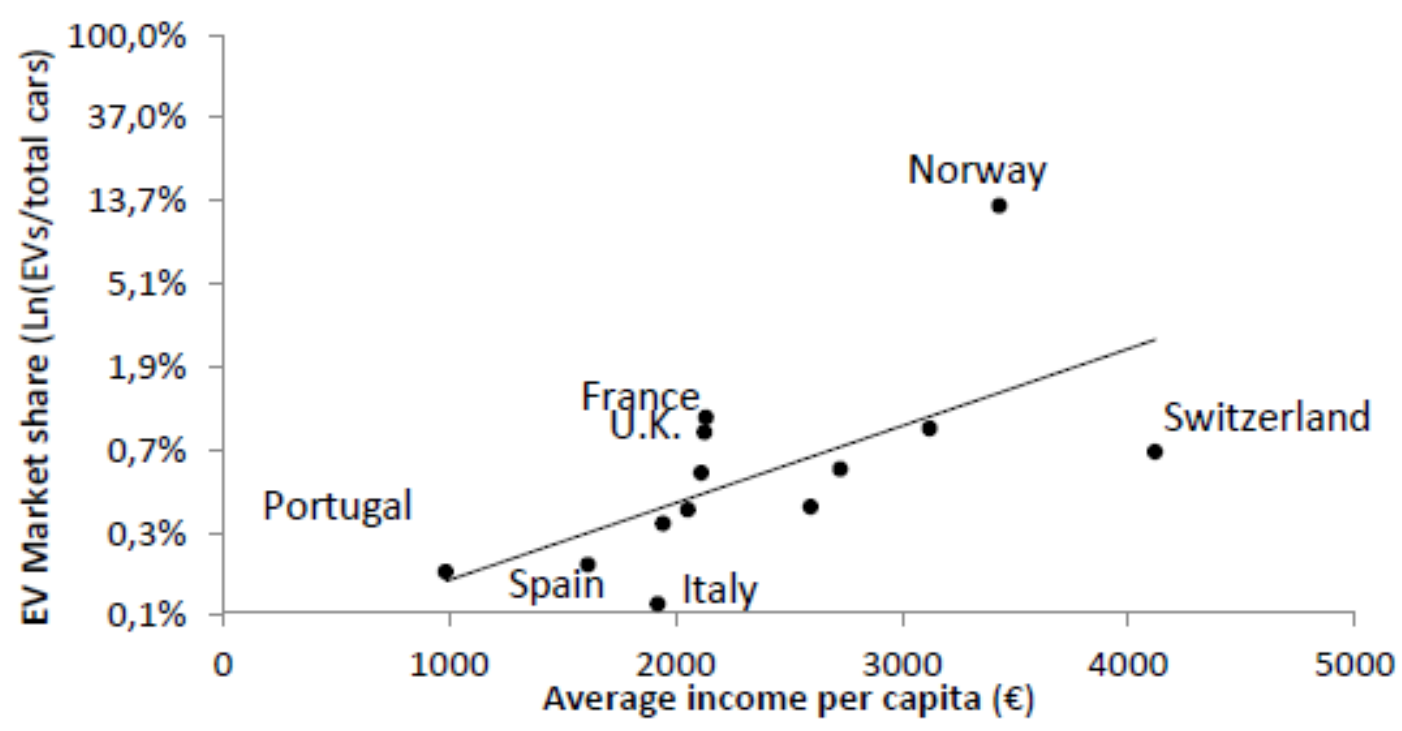

Figure 5. EV market share vs average income per capita per country

Notice that three of the higher fabrication countries of EVs and PHEVs are also in the top five most selling countries, reinforcing the choice of a point in-between them to locate the remanufacture plant. Indeed, United Kingdom, France and Germany are the countries where the best selling European car manufacturers fabricate their EV models.

Moreover, Netherlands, United Kingdom and Germany are three of the countries with worse electricity MIX in Europe (above $500 \mathrm{gCO}_{2} \mathrm{e} . / \mathrm{kWh}$ ) needing immediate and important entrance of renewable energy sources to decrease these values. Therefore, these countries will certainly need the support of ESS 
to enhance its entry, becoming potential clients to buy $2^{\text {nd }}$ life batteries. Additionally, Denmark is also positioning towards Eolic generation, which will certainly need some grid support.

On the other hand, countries with important renewable electricity share, such as Spain, with more sun radiation than northern countries that could take profit of solar panels installations on rooftops as decentralized energy power generators, forbid by law the use of ESS of any kind to store energy. In contraposition, Germany is planning to enhance the use of ESS so there is more control of the energy injected to the grid by these solar generation systems installed by individual owners. Maybe when legislation considers ESS in southern countries would be interesting to recalculate this location.

\section{Conclusions}

This article presented the difficulties related to the EV EoL determination and the impact on second life management of their batteries.

According to the SOH of batteries after collection, different second life opportunities and their share were obtained. Around a $10 \%$ of recovered batteries will return into the automotive industry as spare parts; close to $70 \%$ of the remanufactured batteries will end up in high capacity installations; finally, 20\% of batteries could be dismantled into modules and cells to prepare new remanufactured batteries to be used on low capacity demanding systems.

Finally, West Germany shows to be an appropriate location to settle the remanufacture plant. It is close to the best EV selling countries, in the country where the majority of European EVs are manufactured and near countries with high income per capita. Moreover, Germany and other close countries (such as Netherlands, U.K and Denmark) have to strongly decarbonize their electricity grid in the following years. Thus, it provides high chances to install ESS on the electricity grid, being the second life of EV batteries a nice decoy.

\section{Acknowledgements}

The authors would like to thank the Universitat Politècnica de Catalunya (UPC) and the project REFER COMRDI15-1-0036 funded by ACCIÓ and European Regional Development Fund (FEDER). 


\section{References}

Ahmadi, L., Fowler, M., Young, S.B., Fraser, R.A., Gaffney, B., \& Walker, S.B. (2014). Energy efficiency of Li-ion battery packs re-used in stationary power applications. Sustainable Energy Technologies and Assessments, 8, 9-17. Elsevier Ltd. https://doi.org/10.1016/j.seta.2014.06.006

Akhil, A.A., Huff, G., Currier, A.B., Kaun, B.C., Rastler, D.M., Chen, S.B. et al. (2013). Electricity storage bandbook. Report SAND2013-5131. Available online at: http://www.emnrd.state.nm.us/ECMD/RenewableEnergy/documents/SNL-ElectricityStorageHandbook2013.pdf

Andrew, B. (2009). Performance, charging and second use considerations for lithium batteries for plug-in electric vehicles. The electricity storage association meeting, session on transportation and grid. Institute of Transportation Studies. Available online at: http://escholarship.org/uc/item/2xf263qp\#page-1

Barré, A., Deguilhem, B., Grolleau, S., Gérard, M., Suard, F., \& Riu, D. (2013). A review on lithium-ion battery ageing mechanisms and estimations for automotive applications. Journal of Power Sources, 241, 680-689. Available online at: http://www.sciencedirect.com/science/article/pii/S0378775313008185 (Accessed: November 2013)

Botzen, W., Gowdy, M., \& Bergh, J. Van den. (2008). Cumulative $\mathrm{CO}_{2}$ emissions: Shifting international responsabilities for climate debt. Climate Policy, 8(6), 569-576. Available online at: http://www.tandfonline.com/doi/abs/10.3763/cpol.2008.0539 https://doi.org/10.3763/cpol.2008.0539

Burns, J.C. (2011). High precision coulometry as a technique for evaluating the performance and lifetime of li-ion batteries. Dalhousie University.

Canals Casals, L., Amante García, B., \& Castellà-Dagà, S. (2016). El envejecimiento de las baterías de un vehículo eléctrico y cómo lo percibe el conductor. Dyna Ingenieria E Industria, 91(3), 188-195. Available online at:

http://www.revistadyna.com/Articulos/Ficha.aspx?IdMenu=a5c9d895-28e0-4f92-b0c2$\underline{\mathrm{c} 0 \mathrm{f} 86 \mathrm{f} 2 \mathrm{a} 940 \mathrm{~b} \& \mathrm{Cod}=7599 \& \mathrm{\&} \text { dioma }=\mathrm{es}-\mathrm{ES}}$

Canals Casals, L., Martinez-Laserna, E., Amante García, B., \& Nieto, N. (2016). Sustainability analysis of the electric vehicle use in Europe for $\mathrm{CO}_{2}$ emissions reduction. Journal of Cleaner Production, 127, 425-437. https://doi.org/10.1016/j.jclepro.2016.03.120

Canals Casals, L., Schiffer-González, A., Amante García, B., \& Llorca, J. (2015). PHEV battery ageing study using voltage recovery and internal resistance from On-board data. IEEE Transactions on Vebicular Technology, 65(6). Available online at: http://ieeexplore.ieee.org/lpdocs/epic03/wrapper.htm?arnumber=7169612 
Cready, E., Lippert, J., Pihl, J., Weinstock, I., Symons, P., \& Jungst, R.G. (2003). Technical and Economic Feasibility of Applying Used EV Batteries in Stationary Applications A Study for the DOE Energy Storage Systems Program. Albuquerque. https://doi.org/10.2172/809607

Cruz-Gibert, H., Cruz-Zambrano, M., Canals Casals, L., Castellà-Dagà, S., \& Díaz-Pinos, P. (2015). Sunbatt: Use of a Second Life Battery System from PHEV in Stationary Applications. Smart City Expo World Congress. Barcelona. Available online at: http://www.smartcityexpo.com/

Dunn, B., Kamath, H., \& Tarascon, J.-M. (2011). Electrical energy storage for the grid: a battery of choices. Science (New York, N.Y.), 334(6058), 928-35. Avalable online at: http://www.ncbi.nlm.nih.gov/pubmed/22096188 (Accessed: February 2014)

Fernández-Reyes, R. (2014). El objetivo cimático por debajo de $2^{\circ} \mathrm{C}$ en el diario el país. Prismasocial, (12), 436-473. Available online at: http://www.isdfundacion.org/publicaciones/revista/numeros/12/secciones/tematica/pdf/t-13-objetivo-climatico-436473.pdf

Gil-Agusti, M., Zubizarreta, L., Fuster, V., \& Quijano, A. (2014). Baterias: Estado actual y futuras tendéncias (1 ${ }^{\text {a }}$ parte). DYNA Ingeniería e Industria, 89(6), 584-589. Available online at: http://www.revistadyna.com/busqueda/baterias-estado-actual-y-futuras-tendencias-1-parte

Gohla-Neudecker, B., Bowler, M., \& Mohr, S. (2015). Battery $2^{\text {nd }}$ life: Leveraging the sustainability potential of EVs and renewable energy grid integration. 5th International Conference on Clean Electrical Power: Renewable Energy Resources Impact, ICCEP (311-318).

Guenther, C., Schott, B., Hennings, W., Waldowski, P., \& Danzer, M.A. (2013). Model-based investigation of electric vehicle battery aging by means of vehicle-to-grid scenario simulations. Journal of Power Sources, 239, 604-610. Available online at: http://www.sciencedirect.com/science/article/pii/S0378775313003066 (Accessed: November 2013)

Gyuk, I., Jonson, M., Vetrano, J., Lynn, K., Parks, W., Handa, R. et al. (2013). Grid Energy Storage.

Hansen, J., Kharecha, P., Sato, M., Masson-Delmotte, V., Ackerman, F., Beerling, D.J. et al. (2013). Assessing "dangerous climate change": required reduction of carbon emissions to protect young people, future generations and nature. PloS one, 8(12), e81648. Public Library of Science. https://doi.org/10.1371/journal.pone.0081648

Heil, M.T. (1997). Inequality in CO2 emissions between poor and rich countries. The Journal of Environment Development, 6(4), 426-452. Available online at: http://jed.sagepub.com/content/6/4/426.short https://doi.org/10.1177/107049659700600404 
Heiskanen, J., Kaila, J., Vanhanen, H., Pynnönen, H., \& Silvennoinen, A. (2013). A look at the European Union's End-of-Life Vehicle Directive-Challenges of treatment and disposal in Finland. 2nd International Conference on Final Sinks.

IEA. (2013). Energy Policy Highlights. Available online at: https://www.iea.org/publications/freepublications/publication/name,43515,en.html

Jiao, N., \& Evans, S. (2016). Business Models for Sustainability: The Case of Second-life Electric Vehicle Batteries. Procedia CIRP, 40, 250-255). Elsevier B.V. Available online at: http://www.sciencedirect.com/science/article/pii/S2212827116001293

Keeli, A., \& Sharma, R.K. (2012). Optimal use of second life battery for peak load management and improving the life of the battery. 2012 IEEE International Electric Vebicle Conference (pp. 1-6). Greenville, SC: IEEE. Available online at: http://ieeexplore.ieee.org/lpdocs/epic03/wrapper.htm?arnumber=6183276

Lymperopoulos, N. (2014). Commercialization of Energy Storage in Europe. Available online at: http://www.energystorageforum.com/europe/free-white-paper

Martinez-Laserna, E., Sarasketa-Zabala, E., Stroe, D., Swierczynski, M., Warnecke, A., Timmermans, J.M. et al. (2016). Evaluation of Lithium-ion Battery Second Life Performance and Degradation. IEEE Energy Conversion Congress and Expo. Milwakee.

Muenzel, V., \& Mareels, I. (2015). PV Generation and Demand Mismatch: Evaluating the Potential of Residential Storage. IEEE PES ISGT. Washington. Available online at: http://ieee-isgt.org/

Müller, D.B., Cao, J., Kongar, E., Altonji, M., Weiner, P.-H., \& Graedel, T.E. (2007). Service Lifetimes of Mineral End Uses. Minerals Resources External Research Program.

Neubauer, J., Simpson, M., Neubauer, J., \& Simpson, M. (2015). Deployment of Behind The Meter Energy Storage for Demand Charge Reduction.

Oguchi, M., \& Fuse, M. (2015). Regional and longitudinal estimation of product lifespan distribution: A case study for automobiles and a simplified estimation method. Environmental Science and Technology, 49(3), 1738-1743. https://doi.org/10.1021/es505245q

Pachauri, R.K., Allen, M.R., Barros, V.R., Broome, J., Cramer, W., \& Christ, R. (2014). Climate Change 2014 Synthesis Report. Available online at: http://www.ipcc.ch/pdf/assessment-report/ar5/syr/SYR AR5 FINAL full.pdf

Rastler, D. (2010). Electricity Energy Storage Technology Options.

Saxena, S., Le Floch, C., Macdonald, J., \& Moura, S. (2015). Quantifying EV battery end-of-life through analysis of travel needs with vehicle powertrain models. Journal of Power Sources, 282, 265-276. Elsevier B.V. https://doi.org/10.1016/j.jpowsour.2015.01.072 
Schewe, J., Levermann, A., \& Meinshausen, M. (2010). Climate change under a scenario near $1.5^{\circ} \mathrm{C}$ of global warming: Monsoon intensification, ocean warming and steric sea level rise. Earth System Dynamics, $1(1), 25-35$.

Sierzchula, W., Bakker, S., Maat, K., \& Van Wee, B. (2014). The influence of financial incentives and other socio-economic factors on electric vehicle adoption. Energy Policy, 68, 183-194. Elsevier. https://doi.org/10.1016/j.enpol.2014.01.043

Smith, K., Earleywine, M., Wood, E., Neubauer, J., \& Pesaran, A. (2012). Comparison of Plug-In Hybrid Electric Vehicle Battery Life Across Geographies and Drive Cycles. 2012 SAE World Congress and Exbibition. Available online at: http://papers.sae.org/2012-01-0666/

Tong, S.J., Same, A., Kootstra, M.A., \& Park, J.W. (2013). Off-grid photovoltaic vehicle charge using second life lithium batteries: An experimental and numerical investigation. Applied Energy, 104, 740-750. Available online at: http://linkinghub.elsevier.com/retrieve/pii/S0306261912008495 (Accessed: January 2014)

UNFCCC. (2015). Paris Agreement (1-16). Available online at: http://unfccc.int/paris agreement/items/9485.php

Waldmann, T., Wilka, M., Kasper, M., Fleischhammer, M., \& Wohlfahrt-Mehrens, M. (2014). Temperature dependent ageing mechanisms in Lithium-ion batteries - A Post-Mortem study. Journal of Power Sources, 262, 129-135. Elsevier B.V. Available online at: http://linkinghub.elsevier.com/retrieve/pii/S0378775314004352 (Accessed: July 2014)

Williard, N., Tsui, K.-L., \& Pecht, M. (2011). A comparative review of prognostics-based reliability methods for Lithium batteries. 2011 Prognostics and System Health Managment Confernece, 1-6. IEEE. Available online at: http://ieeexplore.ieee.org/lpdocs/epic03/wrapper.htm?arnumber=5939585

Zhang, J., \& Lee, J. (2011). A review on prognostics and health monitoring of Li-ion battery. Journal of Power Sources, 196(15), 6007-6014. Elsevier B.V. Available online at: http://linkinghub.elsevier.com/retrieve/pii/S0378775311007865 (Accessed: November 2013)

Journal of Industrial Engineering and Management, 2017 (www.jiem.org)

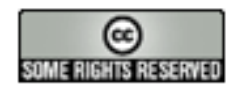

Article's contents are provided on an Attribution-Non Commercial 3.0 Creative commons license. Readers are allowed to copy, distribute and communicate article's contents, provided the author's and Journal of Industrial Engineering and Management's names are included. It must not be used for commercial purposes. To see the complete license contents, please visit http://creativecommons.org/licenses/by-nc/3.0/. 